\title{
A difícil viagem de retorno à aldeia ${ }^{1}$
}

\author{
OSWALDO ELIAS XIDIEH
}

Não procurei rastrear a presença do oprimido na literatura popular, nem na erudita.

Ocorreu-me, apenas, um intenso desejo de apresentar-lhes alguma coisa viva, pulsante, latejante, dolorosa: o migrante. Vocês ouvirão, como desde agora eu oiço, ele sendo contado, recitado, cantado por milhares de bocas anônimas - caipiras,

piraquaras, capiaus, tabaréus, peões, crias, mumbavas - destes Brasis sem fim. Que se aproximem os senhores da outra literatura, que se acheguem e aportem com mão limpa e olhos despidos e escrevam, pelo amor ao povo, não outras vinhas da ira, o Horto da Agonia, meus senhores, sim.

Oswaldo E. Xidieh

$\mathrm{F}$ AZ MUiTos ANOS, em fins da década de 1960, ao escrever o primeiro texto de Semana Santa cabocla ${ }^{2}$, duas preocupações instigantes se me propuseram: o destino da cultura popular ao embate das mudanças de todos os tipos que, de há tempos, se desencadearam no Estado de São Paulo e a destinação do trabalhador braçal em crise existencial, alijado do seu espaço, acuado para outra esfera de relacionamento social - a sociabilidade formal da sociedade hegemônica - e que, desgarrado do seu sistema cultural, pedra básica do seu comportamento e da sua representação no mundo, passa a ser simplesmente o outro, o indivíduo e não mais pessoa.

Quanto à primeira preocupação, ignorando quaisquer impulsos sentimentalistas e saudosistas, que, na verdade, apenas encobrem e dissimulam tendências pessoais e reacionárias; examinando, doutro lado, todo o elenco das injunções que se exercem sobre a cultura popular de modos a esvanecê-la e a reduzir os grupos populares aos objetivos e interesses da sociedade hegemônica (a cultura de massa ou a indústria cultural), o problema se clarifica.

A cultura de massa, já velha de cento e tantos anos ${ }^{3}$, veicula valores, modelos de comportamento, padrões estéticos e cria necessidades dosadas para as diferentes classes sociais a fim de mantê-las nos seus devidos lugares, satisfeitas e participantes dos bens de consumo e das benesses do sistema capitalista - mas isso não se constitui numa exclusividade desse sistema... Quando acionada, também de fora para dentro, por grupos de vanguarda, pretendendo ensinar o povo a produzir a verdadeira arte popular (o que não significa apenas arte) é timidamente ideológica e utopicamente revolucionária ${ }^{4}$. 
É normal que o sistema capitalista deva cumprir-se em todo o seu processo no qual se inclui o nivelamento-absorção constante de formas e forças que the são antagônicas. No entanto, os bens e as idéias propostos ao consumo não chegam às classes básicas, inclusive aos "bóia-fria", que não têm, por impossibilidade econômica, chances de usufruir muitos deles. Resta, então, uma esperança para a cultura popular...

É curioso que muitos grupos de vanguarda tenham uma visão obliterada do que no Brasil costumam definir como povo alienado. Quem é o alienado historicamente no Brasil: o povo ou o Estado? Quem deve ser alinhado? Não estaria essa vanguarda intelectual, espécie de nova aristocracia, assumindo a posição dos socialistas feudais aos moldes de 1838?

Mas, deixemos de lado essa primeira preocupação e partamos de dados concretos e, no momento atual, irreversíveis. Mudanças extensas e profundas processaram-se no sistema de trabalho e de produção, de posse e uso da terra, da circulação de bens; na transformação do trabalhador braçal em operário desvinculado de qualquer fixação à terra e de compromissos patronais e na sua urbanização; na destruição sistemática da natureza fornecedora de bens materiais e das comunidades em que se perpetuavam usos e costumes, crenças e cerimônias tradicionais. Assim foi que a cultura popular recebeu sérios golpes, mas, nem por isso, desapareceu.

Quando desaparecerá? Só mesmo invadindo o campo da utopia ou da literatura tipo Admirável mundo novo e 1984: superestruturas sociais altamente racionalizadas, no último limite de especialização das suas ciências e tecnologias, isto é, no patamar ideal das suas ideologias, em computadores especiais, tabulariam todas as necessidades humanas e programariam as satisfações permissíveis. Simultaneamente, em laboratórios de genética-corretiva, preparar-se-iam espermas que, inseminados em mulheres (talvez mesmo isso seria dispensável) resultassem na produção pacífica e em série dos que deveriam ser peças utilizáveis na estratificação e na estrutura sociais. Seria a glória final de ambos os sistemas políticos hoje senhores do mundo se chegassem, ao lado daquelas conquistas, a neutralizar o processo da dinâmica social e a destruir, com lavagens cerebrais e drogas específicas, as dimensões do homem...

Não nos preocupemos, portanto, com o destino da cultura popular. Pã não morreu. Pã é a natureza humana, criadora de signos, símbolos, mitos e vida. Ele é a variedade, a diferenciação, a ambigüidade; é ser-não-ser-estar-sendo e, acima de tudo, irracional em oposição à racionalidade instituída e imposta...

\section{Os bóias-frias de Marília}

A segunda preocupação procede e, no dia-a-dia, nestes últimos vinte e tantos anos, acompanhando a vinda e a ida de grupos de trabalhadores braçais em Marília $^{5}$, em busca de trabalho junto às propriedades agrícolas e pastoris da região, foi possível estabelecer as etapas da sua odisséia. 
Em 1962, já sabíamos alguma coisa a respeito dos retirantes. Eram pequenos grupos que, de início, procuravam a delegacia de polícia da rua Gonçalves Dias, pedindo abrigo, encaminhamento ao Albergue Noturno e auxílio para viajar. Aos poucos, entre 1963 e 1964, esses grupos se avolumaram e passaram a se acomodar sob o telheiro de um antigo armazém na rua Bahia junto à estrada de ferro - a "Flor Roxa”. É a partir, principalmente dessa época, que os agricultores da região se interessam por essa mão-de-obra flutuante, mormente por ocasião das colheitas, e que se configura o tipo de intermediário agenciador de mão-deobra para os fazendeiros: o "gato". Ademais, coincide com a aparição dos "bóiasfrias" a saída das fazendas de uma mão-de-obra mais capacitada (pedreiros, tratoristas, "paus para toda a obra"), atendendo às solicitações urbanas na indústria, na construção e nos empregos junto às repartições públicas. Sobre tudo isso pairam os dispositivos de uma legislação trabalhista não muito clarificadores nem abrangentes ${ }^{6}$.

Os proprietários optam por aceitar trabalhadores que não se fixam no local de trabalho; os "prestadores de serviço" se acomodam em bairros periféricos da cidade. As fazendas se esvaziam ${ }^{7}$, só conservam velhos colonos, já aposentados, remanescentes de um outro sistema de relacionamento patrão-empregado. Há restrições: alguns "bóias-frias" têm permissão temporária para morar numa das casas das velhas colônias, desde que não tenham filhos menores e parentes improdutivos. Evita-se, dessa maneira, um acréscimo de obrigações e ônus para o proprietário e oportunidade de vir o trabalhador, mais tarde, reclamar junto ao Fórum um rol de direitos e compensações.

De onde afluem os “bóias-frias”? Dos Estados de São Paulo, do Paraná, de Minas Gerais e do Nordeste, principalmente. Já circularam pelos três primeiros Estados. Em Marília, em que bairros e em que locais eles de fixaram e fazem "ponto"? Bairros: Vila Coimbra, periferia da Vila Jardim, Palmital, Costa e Silva, Nova Marília... Pontos: Morro do Querosene, no fim da rua 9 de julho; avenida República, defronte à Dismepe; Nova Marília, defronte à padaria... Nesses e noutros pontos menores, são os "bóias-frias" arrebanhados de madrugada pelos turmeiros ou "gatos".

Como se faz o pagamento? Os pequenos arrendatários pagam à vista diariamente. Os fazendeiros, para a colheita da lavoura branca, do amendoim, por exemplo, mandam pagar diariamente; para a colheita mais demorada, do café, por exemplo, mandam pagar semanalmente. Os pagamentos são feitos pelos administradores ou fiscais da fazenda.

Toda a história dessa situação vai ser contada numa nota à parte ${ }^{8}$. O importante agora é verificar como essa mão-de-obra se coloca na cidade, evitando, na medida do possível, o emprego de certas categorias sociológicas que terminam por escamotear a realidade que se aborda. Fiquemos, por ora, com o termo colocação. Prudência: estamos na presença de grupos humanos, na sua quase totalidade provenientes de comunidades rurais brasileiras regionalmente diferen- 
ciáveis, porém, partícipes de uma cultura tradicional que nucleia um conjunto de valores e modelos de ação nacionais. O sistema de convívio - que não pretendo denominar de sociabilidade - está ali implícito.

Dos diversos bairros em que o "bóia-fria" fixa residência, tomei como amostragem a Vila Coimbra ${ }^{9}$ e isso devido a três motivos principais: ali se concentra um grande grupo desses trabalhadores; está mais próximo do ponto de embarque diário para o trabalho ${ }^{10}$ e principalmente, porque mantenho laços de amizade com alguns dos que ainda trabalham na lavoura ou que passaram a trabalhar na cidade como guardas, jardineiros e vendedores de sorvete e pipoca ${ }^{11}$. Ora, tudo o que não foi possível registrar mediante entrevistas, visitas e encontros em botequins, aqueles amigos o fizeram por mim, anotando queixas, esperanças, temores, lá no seu convívio diário.

Esse povo se acomoda em casas, cortiços, barracos de fundo de quintal, porões, quase sempre em péssimas condições, com sanitários, tanques e medidor elétrico coletivos. Nem sempre pode dispor de um quintal para plantar alguma coisa; quando tem essa vantagem, não planta: furtam-lhe tudo. O aluguel das acomodações varia de mil a sete mil cruzados mensais; um cômodo, mil cruzados; quarto, sala e cozinha no cortiço, de três a cinco mil cruzados; casa com dois quartos, sala e cozinha, sete mil cruzados, de modo que somente as famílias com membros "rentáveis" têm a possibilidade de alugá-la. Mas, em qualquer uma dessas acomodações, não há conforto; há promiscuidade, onde se amontam de quatro a dez pessoas que, à noite, dormem aproveitando qualquer espaço no quarto, na sala e na cozinha, quando não num cômodo só.

A vizinhança é outro problema. Anterior à fixação do "bóia-fria”, já havia ali uma população marginalizada, sempre às voltas com a polícia: maconheiros, traficantes, ladrões, prostitutas, menores delinqüentes que infernizam o bairro ${ }^{12}$ e trazem os trabalhadores em permanente estado de alerta: deixar sempre uma pessoa na casa enquanto se vai trabalhar, não permitir que as meninas andem pelas ruas desacompanhadas, nem mesmo para ir à escola, não deixar fora da casa, de dia ou de noite, roupas ou quaisquer objetos. Quando não há furtos, há invariável depredação.

Junta-se a esse problema, para o "bóia-fria”, um outro que o leva ao desespero: os meninos, seus filhos menores, não capacitados para o trabalho na lavoura, ficam o dia todo, com raras exceções, na rua e vão se juntando às quadrilhas e aos bandos de menores delinqüientes. Como exceções, sabemos de alguns meninos que trabalham em supermercados como embaladores de mercadoria, incorporados à política mirim ou como office boys no comércio local.

Há épocas em que o trabalho na lavoura se interrompe. Passado, por exemplo, o ciclo das colheitas, o trabalhador se preocupa com o orçamento familiar e se vê obrigado a mandar suas filhas e sua esposa trabalharem como domésticas ou faxineiras. Sabemos de moças que se prostituíram, porém, acompanhamos um grande número delas que se inscreveu em cursos noturnos de corte e costura 
e até em cursos de segundo grau. Em ambos os casos efetua-se um processo de ajustamento dessas moças à nossa sociedade que lhes oferece, para opção, duas esferas de inserção: uma em que a criatura se estanca como utilidade a serviço do bem-estar e da ordem social, de outra que lhe dá acesso à escalada social. Transitaram.

Acumulam-se, portanto, para o "bóia-fria”, angústias, problemas, inseguranças e temores. A cidade lhe é estranha e ele está apenas colocado nela. Um lamento: "A gente não tem com quem falar de coração. Os vizinhos são como eu, sem parentes, sem compadres, sem amigos. É só isso de trabalhar, vir pra casa e ter medo do dia de amanhã..."13. Outro:

Como é o meu dia? Levanto muito antes da hora de pegar o caminhão do turmeiro, "queimo minha lata", acordo minha mulher que trabalha de cozinheira no Dr. X e entra no serviço às 7,30 . Vou simbora. Ela fica pra arrumar alguma coisa pras crianças. Os dois maiores, de oito e nove anos, vão pra escola. Os dois pequenos, de 5 e 7 anos, ficam trancados na casa até que os dois mais velhos voltem da escola, esquentem a comida deles e deixem que eles brinquem um pouco na rua. Volto de tarde, e, minha mulher, quando já é bem noitinha. É assim ${ }^{14}$.

E mais estes:

A gente está aqui de emprestado e me chamam de Zé. Eu não sou Zé, meu nome é Elpídeo, mas deixa pra lá, qualquer dia, tô juntando dinheiro, volto pra Bahia. Lá, no Caitité, quando não sabem o nome de um homem não dizem que ele é Zé, que isso é xingo pra cabra danado, dizem: homem! ${ }^{15}$

Sabe, a vida que levo é dura e triste porque não temos segurança de nada. Conforme o tempo bom na lavoura, de trabalho seguido, eu e meus dois filhos moços chegamos a ganhar 70 mil e até mais cruzados por mês. Mas vem o tempo ruim. Meus filhos vão se casar qualquer dia desses. Então vem a preocupação com o aluguel deste muquifo que o sr. vê, com as crianças, com a venda, com tudo, sem apelo ${ }^{16}$.

Dessas declarações, destacadas de um rol muito grande, a que me pareceu a mais significativa e essencial e que de qualquer maneira está implícita nas demais é a que revela a solidão do homem transformado em peça mecânica em seu trabalho: "a gente não tem com quem falar de coração" - num conjunto de outras inumeráveis peças estanques numa sociedade racional e utilitarista. Se os membros mais jovens das famílias volantes se ajustam às categorias ocupacionais específicas dessa sociedade, os mais velhos não descobrem nela essas aberturas, porque não as têm previstas segundo o seu código de moral e nem a capacidade de assumir ocupações que, de fato, os transite pela estrutura social vigente. Ocasionalmente, abandonando suas atividades na agricultura, passam à prestação provisória de serviços marginais ${ }^{17}$, almejando sempre um retorno às suas comu- 
nidades de origem. Mas, voltar ao lugar em que se "fala de coração", custa-lhes muito caro; fica-lhes apenas a pulsão de estar junto, integralmente, num contexto em que eles assistem (no sentido arcaico do termo: estar abrigado) e são assistidos (no sentido moderno do termo: ter assistência, ajuda etc.) social e afetivamente, definidos como pessoas. Admito que essa pulsão não seja restrita, nas sociedades hegemônicas contemporâneas, apenas a esses grupos marginalizados; há muita gente por aí que ainda lê, sem coragem de fazer outra coisa, Paul Nizan e Sartre... agoniando-se em raiva e náuseas sufocadas! Casas de campo, mansões com piscina e o culto dos motéis preenchem esse vazio? E os tóxicos?

\section{O "andante" descobre a Umbanda}

Em fins de 1963, fui informado por Alípio dos Santos, biscateiro, ex-trabalhador rural que, na "Tenda de Umbanda São Jorge"18 de Dona Lurdes, aparecia, numa ou noutra reunião, "gente de fora", isoladamente ou em pequenos grupos, e que ele denominou de "andantes". Eram, pois, os migrantes rurais, de passagem ou já, dalgum modo, fixados na cidade que ali se faziam presentes e carentes de soluções para os seus problemas. A partir de 1964, passei a freqüentar a referida tenda interessado, exclusivamente, em acompanhar o migrante e inteirar-me dos seus problemas a fim de saber se, na Umbanda, lhe seriam abertas as vias para acomodação e ajustamento social.

Precisamos enfrentar, de início, algumas dificuldades para discernir quais os grupos de migrantes e os outros grupos de freqüentadores. Dona Lurdes tinha uma lista dos sócios contribuintes, dos nomes dos cambonos e das filhas de santo, porém, dos outros, dos simples freqüentadores necessitados de ajuda espiritual, apenas os nomes, nem sempre completos, registrados em cadernos assim como os seus pedidos. Nenhuma indicação sobre a sua situação profissional, seu lugar de origem e outras informações identificadoras. Interpelada a respeito, ela me respondeu: "Quem vem aqui eu recebo. Tudo é filho de Deus. Não fazendo bagunça na minha Tenda, eu atendo e ajudo. Desordeiro a gente atropela, os respeitadores nós ajudamos e o resto não interessa".

Não bastava, portanto, freqüentar assiduamente as reuniões semanais daquela Tenda e a solução, que me pareceu a mais acertada, foi a de acompanhar de perto os freqüentadores, travar com eles laços de conhecimento e intimidade, estabelecer grupos de amostragem que se renovavam de quando em quando, ao sabor da mobilidade desses grupos e ir anotando, quando não roubando, os seus pedidos, tanto os registrados em bilhetes deixados no pegí, como os consignados em cadernos reservados pela mãe de santo. Isso exigiu paciência, o trabalho de muitos e muitos meses e deu certo: o migrante, numa das fases da sua colocação na cidade, recorre à Umbanda ou a outras agências similares; nem todos os “andantes" são migrantes; nem todos os migrantes são provenientes de áreas distantes e nem percorreram diversos Estados; eles vêm, inclusive, das fazendas da região, e, finalmente, nem todos os migrantes são simples trabalhadores da 
lavoura desempregados: há os migrantes de prestação de serviços urbanos - pedreiros, carpinteiros, mecânicos... Uma realidade que nem sempre é apanhada pelo pesquisador.

O migrante, assim como a maior parte dos que procuram a Umbanda, tem motivos e interesses bem definidos e específicos à sua situação; é, por isso, muito importante que se observem os seus pedidos ${ }^{19}$, sendo, também, imprescindível, que paralelamente se considerem os depoimentos anexos ${ }^{20}$, que nos desvendam necessidades mais profundas.

O migrante não se converte ${ }^{21}$ à Umbanda. Há alguns casos de migrantes que, ajustados a profissões urbanas, se tornaram umbandistas. O migrante aceita a Umbanda na medida em que ela o auxilia a solucionar seus problemas de trabalho, moradia, segurança da família, saúde etc. Mas a Umbanda é simplesmente uma agência mágico-religiosa que, apesar das Federações Umbandistas, não se configura ainda como Igreja e, por isso, não pode oferecer um quadro auxiliar de assistência ampla aos seus participantes, fora das atividades na Tenda, e nem pode acompanhá-los nas vicissitudes diárias de cada um, a não ser pelas recomendações a que se recorram aos banhos de defesa, aos ebós, à queima desta ou daquela vela...

A Umbanda não organizou irmandades, confrarias ou simples associações de crentes, no interior das quais o convívio, limitado apenas aos encontros semanais na Tenda, fosse mais constante, mais abrangente, mais profundo, informal e destituído de qualquer conotação utilitarista (posso mesmo ousar dizer, com o sagrado) e propiciador do reencontro do espírito comunitário, da satisfação à pulsão de estar junto... Mas a Umbanda perdeu o caráter associativo, de inter e intravigilância do Candomblé que, no nordeste do Brasil, preservou a memória, a dignidade e a personalidade do negro que sempre se recusou a ser o outro e sempre lutou para estar junto. Se não com a sociedade branca por um longo lapso de tempo, com os seus próprios grupos nacionais. Creio não ser necessário lembrar Zumbi e Palmares ${ }^{22}$.

Egresso da experiência umbandista, o volante traz, dessa passagem, pelo menos, uma perspectiva renovada de otimismo quanto às questões mais prementes de sua vida diária. Apóia-se, para tanto, nas práticas e nos ritos que ele pode, pessoalmente, observar sem a necessidade de retornar às Tendas. Aceita-os com tranqüilidade: esses ritos e práticas, implícita ou explicitamente, conservam traços, também, do velho catolicismo de folk e da feitiçaria tradicional e difusa (que não de sua experiência e do seu conhecimento) anteriores à passagem umbandista. Em suma, psicologicamente, o volante (ou migrante) rearmou-se para enfrentar algumas crises cotidianas. No mais, continua inseguro: circulará pelos centros espíritas e pelas falsas Ialorixás que cobram fortunas ${ }^{23}$ por seus serviços. Inacessíveis. E, dessa maneira, subsistem os males mais íntimos e incuráveis com paliativos mágico-religiosos. 


\section{A presença do sindicato}

No dia 4 de agosto de 1974 foi reorganizado o Sindicato dos Trabalhadores Rurais de Marília. Está instalado na avenida Sampaio Vidal, no 1181, com um grupo adequado de funcionários e de meios para atendimento odontológico e médico.

Esse sindicato, destinado a atender a quatro municípios da região, Marília, Ocauçú, Guaimbê e Júlio de Mesquita, congrega dez mil trabalhadores, aproximadamente, dos quais, de quatro a cinco mil, no município de Marília. Esses trabalhadores têm ficha de sindicalização, estão cadastrados, o presidente do sindicato permite a vista d'olhos nesse material, porém, apresenta-se imediatamente um entrave para a continuidade da pesquisa em torno da sindicalização do migrante: em nenhum lugar essa designação foi registrada e, muito menos, a de "bóia-fria". Nas fichas não se consignam os sucessivos locais por onde o volante transitou. Aí se apresenta uma dificuldade que só pode ser superada devagar, com paciência, mediante entrevistas com esses trabalhadores nos pontos (as mais rápidas), ou na minha casa (mais demoradas, porém, reticentes). Entrevistas com volantes no Sindicato forneceram-me escassas informações: havia, da parte deles, desconfiança. Fui mais feliz nos encontros com volantes que se afastaram do sindicato e dos trabalhos na lavoura e passaram à prestação de serviços na cidade. E, como não poderia deixar de fazer, entrevistei, também, alguns fazendeiros. Desde que o objetivo era o de colocar a mediação do sindicato nas relações de trabalho trabalhador-empregador e o seu papel de agência de integração social, era necessário que isso fosse feito.

Uma observação preliminar deve ser feita: há sindicatos e sindicatos. Há os sindicatos que oferecem a mencionada assistência médico-odontológica que, no dizer d'alguns, estabelecem laços de ligação paternalista e de dependência moral entre trabalhadores e direção do sindicato, de modo que, "por dever favores", as críticas que aqueles poderiam lhe fazer são evitadas. Seriam esses os sindicatos menores e menos significativos ou expressivos no quadro em que se colocam por categorias os diferentes níveis do proletariado segundo o seu volume, a sua força, a sua consciência de "classe" e o seu poder de exercer injunções diretas sobre a economia e a política?

Há os sindicatos que se voltam inteiramente para a luta operário-patrão e não oferecem nenhum daqueles atendimentos internos: são subterfúgios da burguesia, dizem, para impedir a ascensão do proletariado ao poder. Pretendem-se marxistas, porém, não tenho condições de indicar a que variável ideológica eles se reportam. Seria a dos chavões difusos?

$\mathrm{E}$, finalmente, há os grandes sindicatos que, consubstanciando-se em partidos de trabalhadores, extrapolam-se de suas imediatas funções de mediação, passam a assumir uma posição capital na esfera da produção de bens essenciais à grande indústria e a reivindicar para o proletariado posicionamento em escalada na estrutura social das sociedades capitalistas e das outras, também. Se a força de trabalho é o capital de que o proletariado dispõe, a escalada social é o rendimento que ele exige. 
O que eu pretendo frisar é que os sindicatos dessa categoria têm o mérito de recolocar o trabalhador num sistema de comunitariedade que os primeiros citados não têm, salvo os que se constituem a partir de programação política, ao contrário, portanto, dos grandes sindicatos que se propõem como agências de mediação e, depois, estimulam a formação de partidos políticos da classe obreira. Mas, até onde podem ir esses partidos?

Não podemos ignorar que sua gênese, no Brasil, inspirou-se no modelo fascista italiano na era getuliana: variável estrutural que codifica a negociação e o acordo entre partes litigantes como soluções e nunca a revolução. Nada a acrescentar a não ser uma recomendação: seria interessante analisar o comportamento dos líderes sindicais e o folclore que os caracteriza.

Concluindo, o migrante num Sindicato de Trabalhadores Rurais não encontra vias abertas para seu ajustamento integral à sociedade. Apenas algumas garantias formais quanto ao seu trabalho e à intervenção mediadora nos conflitos dos quais a parte do leão não lhe cabe. Não têm consciência de classe, que só é despertada quando associados aos poucos Sindicatos Rurais mais poderosos das áreas de monocultura intensiva, como a da cana-de-açúcar. Contudo, em ambos os casos, liberar-se ou evadir-se desse nível de trabalho é expectativa de quase todos. Da luta constante para garantir emprego, para reivindicar melhoras salariais e exigir o cumprimento das leis trabalhistas, resulta-lhes um desgaste emocional que, reforçado pelo desgaste derivado das suas precárias condições de vida, os impele para a busca de outras prestações de serviço. Dos poucos evadidos que tive a felicidade de entrevistar ficaram-me depoimentos de cerne resumidos aqui: escapar de um trabalho repetitivo, exaustivo e mecânico - ter tempo para fazer coisas de agrado pessoal - ter momentos de ócio - ter papos de coração em lugar daqueles angustiantes e impessoais em relação ao trabalho e no convívio com outros trabalhadores - ser gente e não ser "Zé" ou "dona Maria" - não estar obrigado a um horário rígido de trabalho que despreza os dias santos precisar conviver com outras gentes do seu próprio nível etc. Haverá nisso tudo, basicamente, uma pulsão de volta à vida em comunidade?

\section{O protestantismo "de imigração"}

O Prof. Elter Dias Maciel, na introdução do seu excelente artigo "Conversão ao protestantismo brasileiro" 24 escreve:

O esforço será no sentido de diagnosticar $[\ldots]$ o que se processa com os indivíduos quando aderem ao protestantismo brasileiro; atendo-nos ao protestantismo "histórico" (batistas, presbiterianos e metodistas, principalmente); o que significa que deixaremos de lado os grupos pentecostais e o protestantismo de "imigração".

Pois bem, foi para estes grupos confessionais que concentramos a nossa atenção. Justificação? Temos tido larga e profunda experiência com esses grupos e não nos passou desapercebida a recuperação, que ali se faz, das vertentes popu- 
lares do cristianismo primitivo e, doutro lado, a abertura que alguns deles oferecem à aceitação de práticas e crenças não especificamente cristãs "reformadas". Estamos na presença de Igrejas, Seitas ou Congregações da classe obreira e dos níveis sociais básicos que, convertidos, observam e mantêm símbolos, práticas e valores consagrados na sua cultura religiosa (de folk) tradicional. É o que vamos colocar, principalmente, ao estudar a igreja que escolhemos para a nossa pesquisa.

O objetivo? O mesmo que nos fez circular pela Umbanda e pelo Sindicato dos Trabalhadores Rurais: saber como se processa o ajustamento do migrante à sociedade urbanizada; verificar até que ponto esse ajustamento é uma simples acomodação a uma situação imediatamente insuperável e, segundo a hipótese por nós levantada, se o ajustamento integrador à sociedade não estaria condicionado ao ajuste prévio, psíquico, do indivíduo a uma comunidade (inclusive religiosa) onde ele se recoloca como pessoa, recupera seus laços de "comunitariedade" e se capacita para enfrentar a sociabilidade formal, impessoal, principalmente quanto ao trabalho e à prestação de serviços.

Dentre as igrejas do mencionado protestantismo de "imigração" ignoramos aquelas por demais exaltativas, exclusivistas, muito judaizantes, em conflito declarado com o mundo dos não eleitos, acusadoras da malignidade implícita nos produtos materiais e espirituais do mundo profano e, finalmente, chegamos à mais "despida" e "aberta" de todas elas: a Igreja do Evangelho Quadrangular. Para nós foi altamente gratificante conhecer o Pastor Adão Francisco dos Santos, sua igreja ${ }^{25}$ e conviver com alguns dos seus 268 fiéis, quase todos antigos migrantes e atuais volantes. Foi assim que conhecemos essa igreja, participamos das suas reuniões, ficamos perplexos perante a complacência em relação à recorrência, ainda que parcial, de contribuições mágico-religiosas em seu ritual.

A Igreja do Evangelho Quadrangular foi fundada pela Sra. Aimée Semple McPherson em Los Angeles, Califórnia, Estados Unidos, em 1922. Ela escreveu um livro: The Foursquare Gospel. Nesse livro, consignam-se as linhas e as bases mestras dessa igreja e se definem os seus objetivos.

Considerando que o Velho Testamento é um conjunto de livros que tratam, principalmente, da história do povo judeu e que foram superados pelas mensagens de Jesus, a Igreja do Evangelho Quadrangular se atém ao Novo Testamento, dando relevância aos quatro evangelistas: Mateus, Lucas, Marcos e João, simbolicamente representados pelo boi (a força), pela águia (o poder), pelo homem (a virtude) e pelo cordeiro (o sacrifício). Esses símbolos expressam as potencialidades do Messias: em Mateus, o Rei que há de vir; em Marcos, Jesus o grande médico; em Lucas, Jesus o Salvador e, em João, Jesus o juiz e o partilhador.

Dos símbolos passa-se à prática: preparar o homem para a vinda do Grande Rei; propiciar-lhe a cura divina, torná-lo digno da misericórdia divina e, para o dia do Juízo, o dia da partilha, garantir-lhe lugar entre os bons e eleitos. 
A prática, isto é, os ritos derivados da simbologia, compreende a vinda do Espírito Santo, a cura divina e o afastamento de entidades espirituais perturbadoras e dos anjos decaídos.

Em seus primórdios, a Igreja funcionava em tendas de lona e, em memória dos quatro evangelistas, instituiu uma bandeira de quatro cores: púrpura, azul claro, ouro e escarlate.

A primeira Igreja do Evangelho Quadrangular no Brasil foi fundada por Haroldo Edwin Williams, em São João da Boa Vista, em 1951. Em Marília, em 1963.

A igreja mariliense está modestamente instalada num salão ajeitado para a realização do culto. Levando em consideração que a quase maioria dos irmãos é constituída de operários, empregadas domésticas e trabalhadores da lavoura, esse culto é (não exclusivamente) feito aos domingos. Nesse dia, os trabalhadores estão folgados, muitos curiosos e visitas podem aparecer, se interessar e, possivelmente, se converter...

O salão é simples e despido de adornos e símbolos religiosos. Na mesa do Pastor apenas a Bíblia, o hinário e o vaso com flores. Bancos e cadeiras. Um órgão. Tudo muito limpo.

Domingo de manhã, sete horas, os irmãos vão chegando e tomando seus lugares. Os doentes (nervosos, angustiados, “obsessionados”, viciados em drogas, em crise familiar etc.) acomodam-se em qualquer lugar.

Oito horas, inicia-se o culto com o Louvor ao Senhor: às exortações do Pastor, aliam-se os cânticos ao ritmo de palmas. Configura-se esse momento do culto como um rito propiciatório à vinda do Espírito Santo que, segundo a crença, ali se fará presente até o final da reunião. Afirma-se, contudo, que mesmo antes da louvação, desde que os irmãos já estejam ali reunidos, o Espírito Santo também está.

Em seguida, é feita a leitura e a interpretação da Palavra, entremeada ou acompanhada por cânticos e palmas, exclamações de júbilo e de alegria.

A coleta de donativos, entre cânticos e palmas, para a manutenção do templo, marca a passagem para a parte final do culto: a Oração da Fé. Nesse momento, a um sinal do Pastor, os carentes passam a ocupar, em pé, a primeira fila na frente dele e do Pastor auxiliar.

A Oração da Féé uma oração específica, feita em nome de Jesus, destinada a propiciar a cura dos doentes, trazer alívio e alegria para os angustiados e afastar espíritos obsessores. É dita com energia. Não é, por assim dizer, reforçada com a imposição de objetos e símbolos religiosos adotados para o exorcismo em outras religiões. Apenas o nome de Jesus.

Os carentes, aos poucos, entram em transe e suas convulsões são controladas pelos Pastores. Coíbem-se as manifestações violentas ou teatrais. As entida- 
des perturbadoras são exortadas para que se identifiquem, se espíritos desorientados de pessoas mortas, se espíritos maldosos enviados por feiticeiros e por invejosos e se malignos, isto é, demônios, anjos decaídos e... exus! Depois de identificados, desmascarados, são expulsos, sumariamente, sem nenhum tratamento comum no espiritismo ou na Umbanda.

Nove horas e trinta minutos, termina o culto durante o qual não houve tomada pelo Espírito Santo. Isso só se dará nas Noites de Vigília, uma ou duas vezes por mês, fora do templo, nalgum sítio ou lugar fora da cidade.

A parte mais significativa foi a da Oração da Fé por consubstanciar uma confluência de crenças e práticas constatáveis desde o Catolicismo de Folk (simpatias e ritos de afastamento, responsos, orações contra Satanás...) até o Espiritismo e a Umbanda. Essa faceta da Igreja do Evangelho Quadrangular faz com que o convertido se sinta em casa: sua conversão não implicou o esvaecimento de traços profundamente arraigados da sua cultura popular. Como veremos, mediante a análise dos depoimentos e entrevistas, aquela abertura dará ao convertido, no seu trato com a sociedade abrangente, disposições de tolerância e respeito.

Mas as atividades dessa igreja não se resumem nos cultos semanais. Como em outras denominações, ela instituiu um sistema de visitação, de auxílio mútuo, de intervigilância que devolve ao grupo de convertidos o sentido de vida comunitária. Esse sentimento, no entanto, não os leva a disposições hostis ao mundo ambiente. Reforça-se na abertura permitida por sua igreja que lhes ensinou o caminho de volta à aldeia onde eles se reequilibram psicologicamente e se capacitam, sem perder sua segurança íntima, para o trato formal, para um sistema de sociabilidade que, dali por diante, não mais lhes castrará a condição de pessoas. Um possível momento conseqüente seria o de integração?

Toda a nossa experiência efetuou-se apenas com um grupo confessional tomado como amostragem. Outras sondagens devem ser feitas: nas Comunidades de Base católicas, nos centros e instituições destinadas à recuperação de transviados e carentes, enfim, em toda e qualquer agência mediadora, constituída em termos de comunidade, onde o outro, o oprimido, o preto, o pobre desamparado, o marginalizado, a prostituta (o refugo social) encontrem amparo e assistência para a sua recolocação como gente, redescobrindo um nós, imediato, de comunidade, que abrirá as vias de passagem para o nós, mediato, de sociedade.

Como qualquer pessoa pode perceber, toda a minha reflexão esteve centrada numa categoria pronominal do guarani referente à primeira pessoa do plural: Orê e ñandê, isto é, só nós e nós mais os outros. O etnólogo pode exumar deles os conceitos de "comunitariedade" e sociabilidade.

\section{Depoimentos dos crentes}

Passemos agora a destacar o que havia de mais importante nos depoimentos e nas entrevistas feitas e dadas pelos crentes e por Adão Francisco dos Santos. 
No encontro com Adão, o assunto versou sobre as relações da Igreja do Evangelho Quadrangular com o mundo profano no que se refere aos usos, costumes, vícios, modas, partidos políticos e religiões. Aí vai um resumo da entrevista:

Nós não adotamos o termo profano para designar os que não pertencem à nossa igreja $[\ldots]$ todos são filhos de Deus; os vícios não são aceitos $[\ldots]$; não proibimos a bebida alcoólica e nem o cigarro aos nossos irmãos, mas fazemos de tudo para que eles evitem ou deixem esses vícios que afastam o homem do Senhor $[. .$.$] , a moda, a roupa é para agasalhar o corpo, não pode ser indecente$ e nem para provocar escândalo [...] não temos proibições de coisas de comer [...] o ruim é o que a boca lança pra fora: a mentira, a calúnia, o mau conselho, a intriga, a palavra de sedução [...] a boa política pode ajudar o povo [...] um irmão, se quiser, pode candidatar-se a vereador [...] todas as religiões são boas, merecem nosso respeito desde que não sejam fanáticas e nem promovam a discórdia entre os homens...

Dos depoimentos dalguns crentes, destacam-se os de Jorge Luiz, Rosalina Marques de Oliveira, Adão Francisco dos Santos e Plínio Penitente, por serem os mais completos, menos repetitivos e mais marcados por uma franqueza estarrecedora.

$1^{\circ}$ - Jorge Luiz, 27 anos de idade; como diarista, foi trabalhador rural; foi engraxate e pintor de parede; residiu sucessivamente em São Paulo, Bauru, Oswaldo Cruz e Americana; atualmente trabalha num banco. Em 1978, converteu-se do catolicismo para a Igreja do Evangelho Quadrangular.

Antes da conversão, sentia-se desprezado por ser pobre, não tinha segurança em lugar algum e partiu para o alcoolismo. Tornou-se pederasta, esperando juntar-se a um grupo de pessoas com o qual pudesse conviver e nele encontrar apoio e compreensão para enfrentar a luta de cada dia. Mais desprezos, maiores discriminações, mais sofrimentos...

Na Igreja, ele encontrou "cura" para o homossexualismo e superou o alcoolismo. Venceu, ele mesmo o confessa, por conviver numa comunidade, as barreiras que o separavam da vida normal de cada um.

Hoje, Jorge Luiz está casado, tem filhos, pretende melhorar de posição no banco em que trabalha como contínuo e se reforça, semanalmente, no culto da sua igreja, porque ali, no convívio com os irmãos, ele começou a ser um homem de respeito.

$2^{\text {o }}$ - Rosalina Marques de Oliveira, 63 anos de idade; foi "bóia-fria” e diarista; atualmente trabalha como doméstica; residiu sucessivamente em Dracena, Jamaica e Vera Cruz; foi católica e se converteu à Igreja do Evangelho Quadrangular em 1966, encontrando ali o que nunca tivera antes: apoio, saúde, paz de espírito e alegria. Sendo viúva, desamparada e sem recurso algum, nessa Igreja encontrou uma família que a ajudou a enfrentar o mundo. 
$3^{\circ}$ - Adão Francisco dos Santos, 32 anos de idade; foi "bóia-fria", diarista e, anteriormente, padeiro, servente de pedreiro e "biscateiro"; agora é funcionário estadual. Em 1966, converteu-se do catolicismo à Igreja do Evangelho Quadrangular, após ter vivido em Dracena, Jamaica e Vera Cruz. Teve decepções com a Umbanda e com o Sindicato. Tinha vícios, era gago, era objeto de zombarias; sentia-se sem capacidade para conviver com os outros, reclamar seus direitos. Só veio a encontrar simpatia, compreensão e ajuda na nova religião. Os irmãos são a sua família e os colegas sinceros, como nunca tivera antes. Abandonou o alcoolismo e o tabagismo e vai, aos poucos, corrigindo a sua gagueira. Hoje ele é pastor auxiliar da sua igreja.

$4^{\text {o }}$ - Plínio Geremias Penitente, 73 anos de idade; foi administrador e fiscal de fazenda; foi serrador, afiador, carpinteiro e maquinista; residiu, anteriormente, em Oswaldo Cruz, Tupã e Borborema. Era ateu e, em 1956-1957, aceitou a fé protestante na Igreja Cristã do Brasil e, depois, passou para a Igreja do Evangelho Quadrangular.

Era comunista. Em Marília, fazia parte da direção do partido (no Sindicato) como $2^{\circ}$ secretário. Em 1957, desligou-se do partido; tinha problemas de ordem existencial e queria saber mais a fundo sobre Deus e o universo: na Bíblia, ele encontrou respostas e soluções para os seus problemas. Com a fé em Deus, ganhou a paz interna, inclusive, paz com a sociedade.

Para encerrar esta sumária relação de casos junto uma declaração de Jorge Luiz, que completa o seu depoimento:

Eu andava de um lugar para outros sem saber onde ficar e num sábado à noite resolvi visitar uma velha amiga, prostituta, que eu não via há muito tempo e encontrei uma pessoa diferente daquela que eu conhecia $[. .$.$] perguntei o que$ tinha acontecido e ela me disse: "aceitei Jesus como meu Salvador, agora sou uma mulher feliz". Vou the contar tudo sobre essa irmã, não anote o nome dela, anote só D.C.

Ela tinha catorze anos quando foi estuprada por dois vagabundos. Não tinha mãe. Caiu na zona e assim foi até o dia em que uma irmã nossa a encontrou na rua em estado lastimável e a convidou para ir ao nosso culto de domingo. Ela foi. Teve a Oração da Fé e foi salva. No começo, um casal de irmãos recolheu D.C. em sua casa. No dia em que ela teve forças para enfrentar o mundo, saiu procurando emprego e até hoje está trabalhando como faxineira. Foi essa mulher que me abriu os olhos e me mostrou o caminho da salvação.

Notas

l Os intertítulos são de responsalibilidade da editoria de Estudos Avançados.

2 Oswaldo Elias Xidieh, Semana Santa cabocla, São Paulo, IEB/USP, 1972.

3 De Ecléa Bosi é imprescindível ver Cultura de massa e cultura popular-leituras de operários, Petrópolis, Vozes, 1972. 
4 De Marilena Chauí ver "Notas sobre cultura popular", em Arte em Revista, 3, pp. 15-21, Kairós, mar. 1980, São Paulo e, nesse mesmo número, de Estavam Carlos Martins, "O que foi o MCP", pp. 67-71 e "História do CPC", pp. 77-82.

5 Marília é uma cidade localizada a oeste do Estado de São Paulo, na região da Alta Paulista, com uma população de, aproximadamente, 180 mil habitantes e distante da capital 443 quilômetros. É um importante centro agrícola, pastoril, industrial e cultural. A instalação do Município de Marília deu-se em 4 de abril de 1929. O desbravamento e a colonização da área mariliense teve início por volta de 1923. Acelera-se a partir de 1928-1930 com a vinda de fazendeiros, agricultores, trabalhadores rurais e prestadores de serviços de outras áreas do Estado, abaladas pela crise que então atingiu todo o Brasil. Restava, pois, a grande área em desbravamento: para lá foram, principalmente, italianos, espanhóis e, quase simultaneamente, japoneses. Na lavoura e no comércio, na medida em que passaram a atuar na cidade, a presença desses grupos étnicos foi bastante positiva (sem referências ao processo de caldeamento que os nivelou à população básica brasileira...).

6 Conforme queixas formuladas por fazendeiros e trabalhadores. $\mathrm{O}$ trabalhador rural diz: "Tudo vai bem até que apareça algum enguiço. Então a gente vai ao Fórum. O Juiz está lá. Tem também os advogados de um lado e do outro. Dizem que eu tenho pra receber uma porção de dinheiro. Falam no tal de acordo e, então, puxa daqui, puxa de lá e eu fico com o que a Luzia ganhou atrás do mato...”. O fazendeiro diz: "Se você receber em sua propriedade um trabalhador braçal numa sexta-feira à tarde ou num sábado e não fizer no ato o registro, deixando-o para segunda-feira, dia em que o admitido começa a trabalhar, pode se aprontar que lá vem confusão. $O$ danado, quase sempre muito bem orientado, na segunda-feira já procura o sindicato, faz sua queixa, reclama todos os seus direitos e, mesmo que se proponha algum acordo, o lesado é sempre você".

Obs.: Pode ser que isso não passe de um folclore inventado a partir das relações conflitantes entre empregados e empregadores. Mas, não haveria, também, um outro folclore derivado da defasagem entre a fixidez dos dispositivos legais e a mudança social?

7 Conforme a informação dada por Jesus Montolar, proprietário da fazenda "Pau d'Alho": "Antes de todas essas complicações que o fazendeiro enfrenta atualmente, nós tínhamos na fazenda 'Pau d'Alho' de 28 a trinta famílias de colonos. Dessas famílias, pelo menos, cinqüenta pessoas tinham condições de trabalhar na lavoura e na prestação de serviços auxiliares. Quando se tornava necessário, no tempo da safra por exemplo, contratávamos até mais trinta trabalhadores. Hoje, abrigamos apenas oito famílias, dentre as quais três estão aposentadas, mas ficam na fazenda porque vêm de um outro tempo, em que ainda havia relações de amizade e compadrio entre patrão e colono. Essas famílias viveram ali muitos anos; não é justo, agora, tirá-las de lá. Eu, também, sou de um outro tempo, do tempo em que se dizia: onde comem dois, comem três... Agora, anote esta observação, o esvaziamento das fazendas se deve, também, à progressiva mecanização das lavouras, à introdução de meios tecnológicos e doutros recursos que vão tornando desnecessária a presença constante do trabalhador em todas as fases do trabalho agrícola. Não é mais preciso que eles morem nas fazendas. Em ocasiões especiais, o turmeiro se encarrega de trazê-las na cidade". 
8 A "história" da abertura da frente agrícola na região mariliense foi levantada mediante as declarações e lembranças do Sr. Quito Nogueira e "realinhadas" com observações feitas por Jesus Montolar. O Sr. Quito Nogueira tem 82 anos de idade. É membro de uma família pioneira e foi fazendeiro. Eis o seu relato:

"Foi assim: entre meados dos anos de 1920 até o começo da década de 1930 era o que nós chamávamos de mato em pé e água do corgo. O dono das terras ainda não desbravadas entregava-se, conforme o princípio de uso e costume estabelecido por lei, a migrantes que vinham com alguma posse e bagagem, isto é, conhecimento do trato com o café. Esses agricultores, italianos e espanhóis, vinham das zonas velhas do Estado de São Paulo, lá da Mojiana, por exemplo. Se você quiser, eu indico os descendentes deles aqui na cidade, os que se transformaram em fazendeiros e negociantes.

Pelo acordo feito, o agricultor recebia a terra, fazia desmatamento e coivara, tombava a terra e fazia a plantação. Segundo o acordo, só nalguns casos o agricultor recebia alguma ajuda do proprietário, mas tinha o direito de plantar milho, mandioca e feijão e arroz para o seu consumo. Esse trabalho poderia durar de quatro a seis anos conforme a safra boa. Se ela acontecesse no quarto ano, o agricultor recebia um pagamento compensador, saía da fazenda ou ali ficava como colono. A safra boa do sexto ano ficava toda para o agricultor.

Muitos desses agricultores compraram sítios ou pequenas fazendas e "enricaram". As fazendas têm suas "colônias", capelas e uma mão-de-obra estável. Têm também campo de futebol. Nelas o colono tem direito de fazer a sua horta, à lenha e ao leite. A situação vai mudar nos anos de 1930. Implanta-se a vinculação empregatícia através da carteira de trabalho, diferente da atual, dividida em três partes: identificação das partes - o tipo de contrato - o conta corrente. Aí você pode ver que já há uma abertura para se recorrer ao juízo.

No contrato, se estabelece o quanto o empregado ia, por trato de cada mil pés de café, receber. Mantém-se ainda o direito do trabalhador ao consumo da lenha e do leite. A norma instituída garante-lhe o direito de dispor de um alqueire de terra para seu usufruto por cada dez mil pés tratados, assim como, a partir dessa quantia de pés de café, o direito de ter, ou de ir tendo de dois a três animais. Podiam ser cavalos, vacas e burros. Cabras e éguas, não. As cabras são daninhas e a urina da égua mata as plantas. $\mathrm{O}$ direito à moradia é respeitado. Os membros œteis da família do colono eram chamados de "enxadas".

Com essa carteira e com as reformas que o Getolio vai fazendo começam as questões trabalhistas que, somadas com a insegurança do comércio do café e das crises que abalam o poder econômico dos fazendeiros, vão mudar completamente o que agora mesmo eu contei. Já é outra carteira de trabalho que reflete a nova legislação trabalhista. $\mathrm{O}$ fazendeiro, devido às crises, perde a possibilidade de pagar os direitos trabalhistas: salário mínimo, férias etc. Sai a norma de desconto de $20 \%$ do salário do trabalhador pela moradia na colônia.

O fazendeiro burla a lei e desconta $20 \%$ do salário de cada um dos moradores de uma mesma casa. O trabalhador passa a pagar a lenha, o leite e a luz. Começa o êxodo para a cidade. A mão-de-obra mais capaz de se ajustar a outras profissões procura as cidades industrializadas de Judiaí, Campinas, Limeira, Americana e São Paulo. Os outros mudam pra cá. Isso, eu acho, estava acontecendo no Brasil inteiro. 
A grande mudança na agricultura, que vai modificar o jeito das fazendas e as possibilidades do trabalhador braçal, aconteceu após as terríveis geadas de 1960. Os cafezais foram destruídos. Vieram as medidas para a salvação e restauração dos cafezais.

O IBC faz financiamento a longo prazo para esse fim. Uma técnica nova é observada para a disposição em curva de nível dos pés de café e para o traçado dos carriadores. Isso parece coisa sem importância, mas não é. Modificou tudo: o trabalho na lavoura do café e a quantia de empregados necessários para esse trabalho. Tornou-se possível então um rendimento maior no trabalho do tratorista. A mecanização dispensou de $70 \%$ a $80 \%$ da mão-de-obra nos tratos culturais: capina, adubação e passar veneno. Quer um exemplo? Na praga da ferrugem, no sistema antigo, era usado um trator com tratorista e mais quatro homens para fazer oitocentos pés de café com resultados precários. Na nova forma, o trator com um tratorista e mais ninguém, em dez horas de trabalho, faz dezesseis mil pés.

Acho que o senhor, pelas suas perguntas, estava mais interessado nisso que eu contei. Não falei de arrendatários, de parceiros, de camaradas, de meeiros e de tarefeiros porque via que o senhor sabia o que eles eram nos trabalhos agrícolas. Alguns desses tipos de mão-de-obra quase não existem mais, o camarada, por exemplo. Agora nós temos esse novo tipo de trabalhador, o volante, o "bóia-fria". Eu sou de outro tempo. Sei que muitos fatores se juntaram para que a situação do trabalhador braçal chegasse a esse ponto. Não me conformo. Acho que foi um jogo de empurra-empurra e que o mais fraco caiu de quatro".

9 Vila Coimbra é um bairro proletário na zona norte de Marília. É considerado como o slum da cidade.

10 No Morro do Querosene, defronte ao "Picadão" na rua 9 de Julho, 2144.

11 Entre outros, Antônio do Nascimento, vendedor ambulante de sorvete; José Alagoano, servente de pedreiro; Matias dos Santos, saqueiro; Abdias Mineiro, volante; Juvelino Pedroso, volante; Edmilson Pessoa, volante; Aurelino Maia, volante; Pedro Antônio, vendedor de pipocas e volante; Mariana de Souza, doméstica, faxineira e volante no tempo da safra.

12 A propósito da marginalização na cidade de Marília, ver a tese de doutorado do Prof. Jayme Wanderley Gasparoto: Mudança sócio-econômica e marginalização em Marília, defendida na Unesp, Campus de Marília, em 1973.

13 Do depoimento de Altamiro Lopes. Altamiro foi colono na Fazenda [...], foi volante e, numa colheita de café, teve o olho direito vazado por um galho seco.

14 Do depoimento de Juvelino Pedroso.

15 Do depoimento de Elpídio Miranda. Elpídio, atualmente, trabalha como guarda e está juntando dinheiro para voltar a São João do Alipe (hoje Jânio Quadros), na Bahia, e ali fazer a sua própria roça e ter o seu criame.

16 Do depoimento de Abdias Mineiro.

17 É o caso de Da. Mariana de Souza, que aspira voltar ao Ceará.

18 A "Tenda de Umbanda São Jorge" estava instalada na rua Humberto de Campos na Vila Palmital e, com a mudança de Da. Lurdes para o Estado do Paraná, encerrou suas atividades em 1974. 
19 Dos 150 bilhetes coletados na tenda de Da. Lurdes (Maria de Lurdes Barreto), foram deixados de lado os que expressavam interesses da média e da alta burguesia, num total de vinte pedidos. De passagem, eis alguns deles: para que o filho seja aprovado no vestibular da Faculdade de Filosofia; para que o marido fazendeiro faça boa compra de terras no Mato Grosso; para que fulano de tal seja reeleito vereador; para afastar o namorado "pé de chinelo" que está iludindo a filha advogada; para acomodar a situação do marido que construiu a mansão, não pagou devidamente o Iapas e se vê às voltas com multas; para ter proteção na viagem que vai fazer de avião; para que a boutique recém-inaugurada seja um grande sucesso etc. Os 130 bilhetes restantes foram tabulados, dando os seguintes resultados: 25 pedidos para não ter aumento de aluguel (19\%); 21 para conseguir proteção para a família (16\%); vinte para conseguir trabalho ou emprego $(15,5 \%)$; dezessete para conseguir cura (13\%); quinze para conseguir uma casa para morar (11,5\%); dez para manter o emprego e não ser dispensado (7\%); dez para resolver questões de família $(7 \%)$; seis para afastar vizinhança ruim $(5,5 \%)$ e seis para proteção contra feitiços $(5,5 \%)$. Constata-se, então, que os bilhetes referentes ao trabalho e à moradia perfazem $53 \%$ do total dos pedidos. De passagem, como amostras, eis alguns deles:

1) Meu Pai Pena Branca não deixa minha patroa, a Dona Mercedes [...] que mora na rua 4 de Abril $\mathrm{n}^{\mathrm{o}}$ [...] me mandar simbora por causa do filhinho que eu levo comigo que eu não tenho quem fique com ele. Anésia Alves. Rua Taquaritinga.

2) $\mathrm{O}$ Badu quer me despejar si eu não lhe pagar mais aluguel que eu não posso que os guia deste terreiro abrande o coração dele. Joaquim Damásio. Vila Coimbra.

3) Salve Caboclo Quebra Galho. Abre um caminho para mim poder achar um lugar pra morar com minha família que não seja no meio de povo ladrão e maconheiro. Osório Alves. Vila Palmital.

4) Estou sem emprego e passando necessidade com minha família o dono do quarto que nós ocupa deu uma semana pra gente sair. Que são Jorge abra o meu caminho e me ajude a arrumar trabalho. Gumercindo dos Santos. Avenida Repœblica.

5) Que os Guias desta Tenda ajudem meu filho Carlos a se livrar dos amigos maconheiros pra poder arranjar trabalho que o turmeiro não quer mais levar ele por causa do vício. Maria Leduina rua das Palmeiras Vila Jardim.

6) O José Turco dono do cortiço cortou a água e a luz pra forçar a gente a sair de lá se não quiser pagar o aumento do aluguel. ????????? a ruindade dele Zé Pilinta. Josefa Cruz. Vila IV Centenário.

Do caderno de registro de pedidos destacamos os que se seguem:

1) Maria Aparecida de Souza, Rua José Bonifácio pede proteção para sua filha Almeirinda que foi deflorada pelo Dr. [...] que agora quer levar ela pra zona de Baurú. Ela me entregou uma fotografia dele e um presente que ele tinha dado pra moça.

2) Emília de Souza, Rua Panamá, quer que seu filho Argemiro de Souza de dezessete anos de idade fique livre da macumbeira Dita Baiana velha de cinqüenta anos que amarrou o moço. Ela me entregou a fotografia e a cueca do moço.

3) Maria Conceição de Paula, da fazenda São José, quer que seu marido que se juntou com uma puta e deixou a família sem nenhum recurso volte pra casa. Ela me entregou o par de sapato dele que ele esqueceu na casa. 
4) Jacira Prado, de Avencas, pede pra dar um jeito no seu filho Antoninho Prado que foi visitar uns parentes em Judiai e voltou com a cabeça virada deu pra beber e abandonou o emprego de motorista. Ela acha que foi feitiço de vingança feito por uma cunhada que não gosta dela. Ela me entregou uma gravata, uma camisa e um par de meias do moço.

5) Isaura Camargo que veio de Odauçœ está brigando com o marido e com os filhos desde o dia em que ganhou dois travesseiros de uma comadre de Presidente Prudente. Os travesseiros ficaram comigo pra examinar.

6) $[\ldots]$ que tem uma grande loja na rua [...] em Marília está indo de mal a pior desde o dia em que o comerciante [...] seu concorrente começou a ir lá todos os dias e sempre às 9 horas da manhã. Já coloquei o nome do inimigo debaixo da pedra.

20 Destaco estes três depoimentos de migrantes que buscaram ajuda na Tenda de Da. Lurdes:

1) De João Berto da Silva, paraibano da região de Campina Grande, 48 anos de idade. Aos dezenove anos de idade foi trabalhar em Pernambuco num canavial. Aos 22 trabalhou em Ilhéus, Bahia, como "pau pra toda a obra". Em 1964, com 24 anos, veio morar em São Paulo onde sofreu muito, trabalhando como ajudante de pedreiro na construção de um grande prédio e por ser chamado de "pau de arara". Saiu de São Paulo em 1966 e procurou trabalho em Marília como jardineiro. Em 1968, começou a trabalhar na lavoura como volante e "bóiafria". Naquele tempo não se falava de sindicato. $\mathrm{O}$ trabalho era muito duro. Voltou a ser jardineiro. Teve muitas companheiras que só lhe deram trabalho e amolação. "Amigos só nos botequins. Acho que o pior inimigo do pobre é outro pobre e o rico caga nos dois".

Nos anos em que João andava muito preocupado, não sabendo bem o que fazer da vida, procurou a Tenda de Da. Lurdes. Freqüentou-a durante quatro meses e sempre saía de lá com mais esperança e mais sossegado. Só por mais três ou quatro dias, depois voltava a gastura. Explicaram-lhe que eram os Exus que, expulsos na Tenda, o agarravam de novo na rua. Por esse motivo é que ele não conseguia trabalho melhor do que ser volante. Afastou-se da Tenda de Da. Lurdes e começou a freqüentar o Centro de Da. Alice na Vila Jokey Clube. Era uma mistura de macumba e espiritismo. A mulher xingava muito e não respeitava ninguém, nem os espíritos. João ficou desconfiado daquilo. Em seguida procurou a casa de Da. Benedita, porém, imediatamente, se afastou de lá; os trabalhos da macumbeira custavam muito caro.

Foi daí que João resolveu trabalhar como guarda particular, juntar todo o dinheiro que lhe fosse possível ganhar e mudar-se para o Estado do Mato Grosso onde alguns paraibanos amigos e parentes seus estavam trabalhando e já tinham comprado umas terras. Não podendo voltar pra Campina Grande, pelo menos, em Mato Grosso ia encontrar o seu povo. "Lá sim, é que se pode viver, pescar, trabalhar e, no tempo do Divino, tocar meu pífano. A zabumba, meu primo toca".

Qualquer dia destes, João vai pra lá.

2) De Elpídio Miranda (já citado mais acima), baiano de São João do Alipe, sessenta anos de idade. Foi agricultor na Bahia. Em 1958, procurando melhoria de vida, 
mudou-se com a família para o Estado de São Paulo. Apesar de ter alguma experiência como carapina, não conseguia trabalho constante. De São Paulo, em 1967, ele veio com a família para Marília. Foi trabalhador braçal por empreitada; foi volante e fiscal de fazenda. Aposentou-se em 1986.

Elpídio confessa que nunca se sentiu bem no Estado de São Paulo; ficava ofendido quando o chamavam de Zé; sua família nunca passou muita necessidade, porém, nunca conseguiu morar em bairro de gente melhor; tinha trabalho, recebia seu ordenado, mas nunca sabia o que podia acontecer no mês seguinte. Os filhos cresceram, ficaram moços, viraram paulistas e começaram a fazer coisas que não eram do seu agrado. A mulher dava-lhes apoio e razão. Começaram as brigas na casa. Ele falava em voltar pra Bahia; a mulher e os filhos faziam caçoada e não concordavam com a mudança. Elpídio separou-se deles, deixou de ser volante e, nestes últimos anos, começou a trabalhar como guarda.

Elpídio foi sindicalizado e teve suas decepções. Nos momentos de crise procurou, com muita fé, a Umbanda e freqüentou a Tenda de Da. Lurdes, assim como outra que havia em Marília. Esperava encontrar orientação e solução para os seus problemas de trabalho e de família. Tomou banhos de defesa, queimou defumadores, riscou um ponto de Ogun na porta de entrada da casa e, para amansar a mulher, acendeu uma vela de sete dias para Oxun e fez um despacho, com vinho branco doce e rosas vermelhas, pra Pomba-Gira.

Disseram-lhe, então, que os Exus tinham sido retirados e que ele já podia falar com os filhos a respeito dos seus desmandos, podendo até convencê-los a voltar para a Bahia. Foi a briga mais feia de toda a sua vida. Nesse dia, Elpídio se convenceu que aquela família não era a sua família e que, de baiano, sobrava só ele mesmo.

Deixou de freqüentar a Umbanda. "Ela é boa, diz ele, para ir acalmando a gente nas horas ruins, mas não acompanha a gente aqui fora. Aprendi uma coisa: meus filhos têm razão, ficaram paulistas, têm seus "papos" e seus jeitos de viver. Não precisam de mim e eu posso, sem nenhum remorso, voltar pra minha terra e pra gente que me entende. Lá eu posso refazer a minha vida. Aqui no sul aprendi um ditado (Boi em terra estranba é vaca) que não serve pra mim. Vim como boi e volto como boi inteiro".

3) De Justino Viana, mineiro de Uberlândia, 48 anos de idade, alguns trechos do seu depoimento oral: "Nasci em 1940 - não conheci meu pai - não fui à escola - minha madrinha Rosa me criou - trabalho desde menino - fui recadeiro homem feito, trabalhei como peão, como camarada e como retireiro - me casei com vinte anos de idade - meu primeiro filho morreu com dois anos de idade meu segundo filho nasceu em 1965 - em 1968 saí de Minas com mulher e filho trabalhei na lavoura em Franca - muito sofrimento e muita necessidade - em 1969 meu segundo filho morreu de anemia - minha mulher endoidou e fugiu com um caminhoneiro - vim pra Marília pra encontrar um peão que era amigo meu lá em Minas - não estava mais aqui - arrumei trabalho como volante cheguei a dormir em carriador de café lá dos lados da Vila São Miguel - não tenho amigos, só conhecidos, e isso é muito ruim - desesperei de encontrar minha mulher - não tenho pra onde voltar - me falaram da Umbanda - fui lá aprendi muita coisa - não resolvi meus problemas, mas ali eu encontrei ajuda e 
pessoas com quem conversar - aceitei uma ilusão para não me matar ou ficar maluco".

Justino Viana amigou-se com uma volante e foi trabalhar numa fazenda de criação na região de Presidente Prudente.

21 Não há conversão à Umbanda a não ser que se queira dar ao termo os significados de adesão, adoção ou participação. No sentido de ruptura, na passagem de uma religião para outra, de todos os valores, símbolos e práticas da religião que se abandona: não há conversão à Umbanda. É óbvio, só há conversão quando precedida pela abjuração. A Umbanda é uma confluência de crenças e práticas derivadas dos cultos africanos, do catolicismo instituído, do catolicismo de folk e do espiritismo, porém, no seu processo de desenvolvimento, na mira de sua universalização, vão se lhe agregando categorias mágicas e religiosas de outras religiões: a cabala, o esoterismo, as religiões orientais... A essa complacência, relativa à aceitação e à incorporação das referidas categorias, junta-se a ilimitada tolerância da Umbanda para com as religiões instituídas. Não se configura ainda como igreja, não criou dogmas nem códigos de discriminação religiosa, não obriga aos que a procuram a abjurarem suas crenças anteriores, assim como não excomunga os que dela se afastam. Para se ter uma idéia precisa do rumo à universalização que se imprime à Umbanda, ver, principalmente, o livro de Woodrow Wilson da Matta e Silva, Umbanda de todos nós, Rio de Janeiro, Freitas Bastos, 1983.

22 A propósito da memória do negro baiano, ver a entrevista dada por Olga do Alaketo à revista Planeta, São Paulo, no 20, 1974, pp. 102-109.

23 A propósito da comercialização de crenças umbandistas em Marília, consultar de Yoshiko Tanabe Mott, O segrego do cofre, tese de doutorado defendida na USP em 1985.

24 Elter Dias Maciel, “Conversão ao protestantismo brasileiro”, Cadernos do ISER, $\mathrm{n}^{\mathrm{o}}$ 1, Rio de Janeiro, Tempo e Presença, 1974, pp. 21-27.

25 A Igreja do Evangelho Quadrangular, em Marília, está localizada na rua 9 de Julho, 368.

RESUMO - ESTUDO do movimento dos migrantes, despojados de sua terra, de sua cultura e das formas de convivência com as quais se afeiçoaram, para irem se colocar em cidades do Estado de São Paulo, entre as quais Marília. Parte destes andantes depositaram suas esperanças e seus pedidos na Umbanda, nem sempre se convertendo, embora ali tivessem encontrado soluções ou encaminhamentos para seus problemas de trabalho, saúde, moradia e segurança. Outros se apegaram ao Sindicato dos Trabalhadores Rurais, que prestava serviços e oferecia possibilidades de acomodação e relativo ajustamento. Houve também quem se aproximasse de ramificações mais abertas da Igreja Protestante, capazes de confortar, converter e oferecer redes de auxílio-mútuo. Depoimentos colhidos pelo autor mostram a dor, a luta e o arrimo que os errantes encontraram nesta andança.

ABSTRACT - THIS ESSAY is a study of the movements of migrants. Deprived of their land, culture and forms of relationship with which they were familiar, they seek to find placement in the cities of the state of São Paulo, including Marília. Part of these vagrants 
placed their hopes and entreaties in Umbanda, albeit not always becoming converts, even if they found in that religion solutions or amendments_for their work, health, housing and safety problems. Others attached themselves to the Rural Laborers Union, which provided services, lodging facilities and relative adjustment. There were also those who approached the more open-minded ramifications of the Protestant Church, providing comfort, conversion and mutual aid networks. Testimonies given to the author show the pain, struggle and support these vagrants found in their wanderings.

Oswaldo Elias Xidieh foi um dos primeiros professores a serem selecionados para a recém-criada Faculdade de Filosofia de Marília, em 1958, futuramente integrada à Unesp. Ali se doutorou em 1965, sob a orientação de Florestan Fernandes, e lecionou até sua aposentadoria. Em 1991, recebeu daquela instituição o título de professor emérito. Escreveu artigos em jornais e revistas especializados - os mais recentes em Estudos Avançados números 30 e 35 - e publicou dois livros: Semana Santa cabocla (São Paulo, Instituto de Estudos Brasileiros, 1972) e Narrativas pias populares. Este, além da edição original, feita também pelo Instituto de Estudos Brasileiros em 1967, foi reeditado em 1993 em co-edição Edusp e Itatiaia. (Nota de Panlo de Salles Oliveira, do IP-USP).

Texto recebido e aceito para publicação em 29 de setembro de 2004. 